\title{
Development of Learning Media Through Mobile Applications in "Production Ecrite Intermediaire" Courses
}

\author{
Jubliana Sitompul $^{1 *}$, Marice ${ }^{2}$, Junita Friska ${ }^{3}$ \\ Universitas Negeri Medan, Medan-Indonesia, \\ jubliana_professeur@yahoo.co.id
}

\begin{abstract}
This research aims to : (1) develop learning media through mobile applications for students in production ecrite intermediare courses; (2) find the opinions of students regarding the use of mobile applications as learning media in production ecrite intermediare course. The implementation of the development uses the Design and Development model which consist of (1) the planning stage, (2) the design phase, (3) the development phase. Whereas student responses were obtained through a survey method with respondents form French Language Deparment students at Medan State University who learn production ecrite intrmediare courses in 2019. The survey result show that $86,1 \%$ students have very good perception and like learning media in the form of mobile application.
\end{abstract}

Keywords: learning media, mobile application, production ecrite

\section{Introduction}

The use of smartphones cannot be separated from people's lives at this time. The first activity most people do when they get up early is to check information on a smartphone. Smartphone comes from the word (smart $=$ smart, phone $=$ cellphone). Smartphone is a mobile device. Mobile in running modern features, such as the internet can quickly send data without physical contact between the two devices (wireless). This tool can also use a free internet network (hotspot), has a lot of multimedia features, internet memory and an increasingly large external memory. [1]

Based on E-Marketer reports, active smartphone users in Indonesia are growing rapidly. In 2015 there were 55 million people and in 2018 there were 100 million people. With this amount, Indonesia became the fourth largest active smartphone user country in the world after China, India, and America. Current smartphone users in Indonesia are dominated by productive age. This age is referred to as millennial generation (15-35 years). The proportion of smartphone usage among millennials is more for entertainment needs. They use an average of 18 hours per day to enjoy watching on demand services, playing games, or just watching conventional television [2].

Based on the development of the phenomenon above, researchers identified several problems. These problems include: educators do not synergize teaching with changes in student behavior (millennial generation). Students use smartphones more for entertainment than learning needs. Writing material is still complex and abstract. Therefore students have difficulty understanding and learning writing lessons. Educators need to find the right teaching 
approach. How to teach according to the needs of this millennial generation. Teachers can utilize smartphone technology as a learning medium based on Mobile Learning (M-Leaning). This technique will provide an atmosphere of new learning experiences. In addition, smartphone technology allows learning opportunities wherever and whenever.

Writing learning in the Production Écrite Intermédiaire course so far has been conventional. This activity takes place using printed textbooks. This situation resulted in a monotonous class and a boring classroom atmosphere. Based on the writer's observation, the use of printed textbooks has several weaknesses. Students often do not bring books, and they are lazy to read. In addition, writing subject matter is still complex, complicated and abstract. This situation causes students to be less motivated to learn it. This has an impact on the ability to write very weak. With a smartphone, the above weaknesses are expected to be minimized so that learning writing goals can be achieved.

Making a mobile application in learning to write on a smartphone will help and arouse students' enthusiasm in studying writing material in the Production Ecrite Intermédiaire course. Writing theories are presented in such a way with interesting pictures and writing learning. Assignments / exercises will be packaged in the form of text and video. The presence of this application will increase motivation to learn to write and the ability to write will be better.

In order for the research to be more directed, the following problem constraints are arranged in the study: this research is focused on the development of learning media based on mobile applications. This application will be used as a source of independent learning for students. The application can only be used online. The material or subject matter in the application is the writing material in the Production Ecrite Intermediaries course.

\section{Research Method}

The development model used in this research is the Design and Development model which is used to produce simple computer-based media products. This means that this model can also be used to develop media based on mobile applications. This application in carrying out its operation requires connection with the computer. This Design and Development Model consists of three stages, namely (1) Planning, (2) Design, and (3) Development [3].

The planning phase is carried out by determining the scope of the learning material, identifying the characteristics of students as users of learning media applications, determining the limits of application development, and gathering material for the material to be contained in the application.

The design phase is the stage of determining the form and content of the application. Activities at this stage include developing initial ideas, conducting concept analysis, making flowcharts and creating story boards for applications.

The development phase includes media production, alpha test, revision and beta test. Alpha test is testing by material validator and media validator. The application is then revised according to input from the material validator and media validator. Revisions are made until the application is declared eligible for use [4]. Beta test is a test by respondents consisting of $3{ }^{\text {rd }}$ semester students of the French Department of Universitas Negeri Medan who are taking the Production Ecrite Intermediare course in 2019. In other words, the Beta Test results are students' perceptions of the applications made. 


\section{Result and Discussion}

Applications made in this study are designed to be operated on all Android-based smartphones. The application is also designed simple so that it can be used by everyone. Therefore this application has finally become like a digital book. The material in this application is the lecture material for the Production Ecrite Intermédiaire material which is presented in 14 sections, as: 1) Ecrire une recette de cuisine1; 2) Ecrire une recette de cuisine 2; 3) Réagir d'un repas: expressions d'appreciations; 4) Ecrire les activités de vacances - La phrase au passé composé - imparfait; 5) Ecrire un souvenir d'enfance - La phrase au passé composé - imparfait; 6) Raconter une soirée - La phrase au passé composé - imparfait; 7) Ecrire une lettre d'invitation - Les pronoms directs et indirects; 8) Faire une action 1- verbe impersonnel et article partitif; 9) Faire une action 2 - construire des phrases en gerondif; 10) Ecrire un projet ou futur - la phrase au futur; 11) Le transport en commun - la phrase utilisant le comparatif et superlatif; 12) Hiver terrible - phrase à la voix passivel; 13) Loisirs - article partitif (renforcement) et verbe faire et jouer; 14) Ma ville - pronom relatif.

Aplha test is carried out by material experts and media experts several times until the application can meet all assessment indicators. Development of alpha test can be seen in the table below.

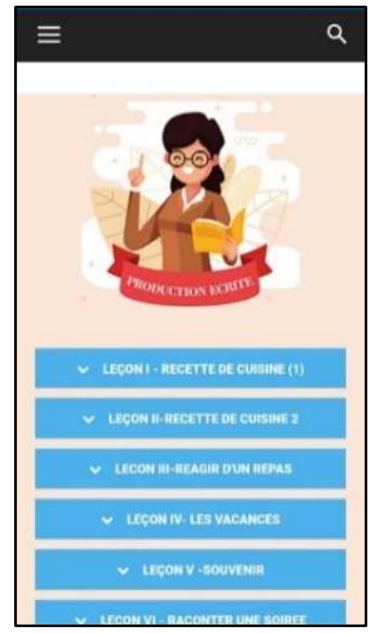

Figure 1. Production Ecrite Intermédiaire

Tabel 1. Alpha Test Result

\begin{tabular}{lll}
\hline Validator & Alpa Test I & Alpa Test II \\
\hline Material Expert I & $92.85 \%$ & $100 \%$ \\
Media Expert & $88.89 \%$ & $100 \%$ \\
Presentage Average & $90.87 \%$ & $100 \%$ \\
\hline
\end{tabular}

In the first test, both material experts and media experts have stated that learning media is very good and feasible to use. Suggestions for revision from material experts are only in the form of improvement in writing the contents of the material that still has errors in writing 
words and punctuation. While media experts give advice, change the type of font used and enlarge the appearance of the text. Media experts recommend that each line of text contains only 5-7 words so that the material is easier to read and does not make the user's eyes get tired quickly.

Whereas based on the results of Beta Tests, the indicator with the highest percentage is in the aspect of quality of content and objectives. Interest and attention get a percentage of $86.7 \%$. This shows that the development of learning media application Production Ecrite is able to attract the interest and attention of students.

The indicator that also gets a large percentage is in the aspects of the quality of the contents and objectives is the completeness of the contents of the learning media with a value of $84 \%$. This shows that the contents of the material and other features in the media are complete so that it helps students in studying electrochemistry.

The indicator with the highest percentage in terms of quality of content and objectives is at the level of importance. The intended level of interest is how important is the use of Production Ecrite learning media in learning Production Ecrite Intermediare subject. The percentage of student assessment results was $81.94 \%$. These results indicate that students consider the use of the Production Ecrite learning media as important and necessary. The media is used as a source of independent learning and helps them to understand learning.

In the aspect of learning quality, the indicator that has the highest percentage is learning flexibility which has a percentage value of $92 \%$. This value is obtained because the Androidbased learning media is able to implement mobile learning so that learning becomes flexible.

The next indicator that has the highest percentage is to provide learning opportunities with a value of $89.3 \%$ and has a very good category. These results prove that the nature of the learning media based on android learning media that is paired on a smartphone device is able to provide learning opportunities to students wherever and whenever.

While the indicators that have the lowest percentage in aspects of learning quality are social quality and learning interaction, which is $80.7 \%$. The interaction given by the media is limited between media and users. However, social and learning interactions will be obtained if students get instructions to discuss the material and questions contained in the media.

The third aspect assessed from the Production Ecrite learning media is technical quality. Technical quality has an average percentage of $87.56 \%$ so it can be categorized very well. This is because the Production Ecrite application is designed very simple. Besides that, another indicator that has a large percentage value is the quality of readability, which is $88.7 \%$. This means that the quality of readability is very good. This shows that the type and size of letters is easy to read.

\section{Conclusion}

The development of learning media based on mobile applications is carried out in three stages: planning, design and development. The resulting learning media is named Production Écrite and can run well on Android-based smartphones.

The validator assessment of learning media based on mobile applications for students in the Production Écrite Intermédiare course is conducted in two stages of assessment. The first assessment (alpha test 1) received a percentage of eligibility of $92.85 \%$ from the material validator and $88.89 \%$ from the media validator. Improvements to the learning media were carried out until the material validator and the media validator gave a $100 \%$ score on the second assessment which meant that Production Écrite was very good and proper to use. 
Student responses to learning media based on mobile applications in the Production Écrite Intermédiare course students is very good. This is shown from the results of a survey which stated that $86.1 \%$ of students had very good perceptions. More specifically, the use of an Android-based mobile application as a learning media makes students feel motivated to study the Production Écrite Intermédiares independently with a percentage of $86 \%$ in the agreed category.

\section{References}

[1] Supardi . (2012). Kiat Memiliki PC Tablet. Jakarta : PT. Elex Media Komputindo.

[2] An. (2018). Penggunaan "Smartphone" di Genggaman Generasi Milenial". Kompas.id. Accessed : 5 Mei 2018 from https://kompas.id/baca/adv_post/penggunaan-smartphonedi-genggaman-generasi-millenial/

[3] Alessi \& Trollip (2001). Multimedia for Learning: Methods and Development. Massachusetts: A Pearson Education Company.

[4] Sugiyono, (2013). Metode Penelitian Kuantitatif, Kualitatif dan R\&D. (13 ${ }^{\text {th }}$-Ed). Bandung : Penerbit Alfabeta. 